\title{
Working
}

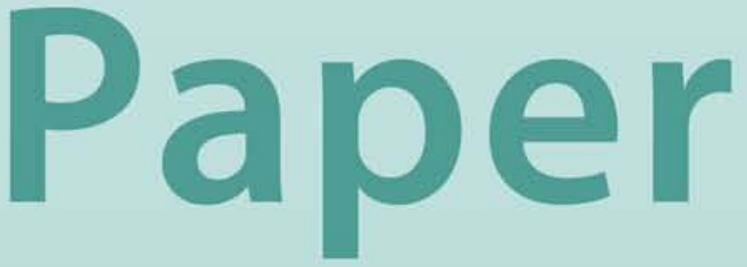




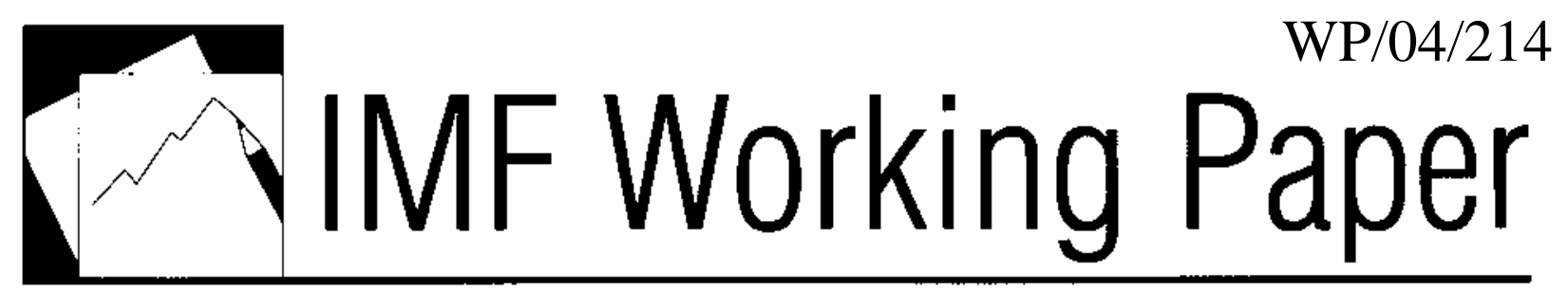

\section{The Distributional Bias of Public Education: Causes and Consequences}

Era Dabla-Norris and Mark Gradstein 


\title{
IMF Working Paper
}

IMF Institute

\section{The Distributional Bias of Public Education: Causes and Consequences}

\author{
Prepared by Era Dabla-Norris and Mark Gradstein ${ }^{1}$ \\ Authorized for distribution by Eric V. Clifton
}

November 2004

\begin{abstract}
This Working Paper should not be reported as representing the views of the IMF. The views expressed in this Working Paper are those of the author(s) and do not necessarily represent those of the IMF or IMF policy. Working Papers describe research in progress by the author(s) and are published to elicit comments and to further debate.

While public education is often intended to be progressive in its effects on income distribution, in reality its incidence is often skewed toward the rich. This paper argues that the extent of this bias is directly related to institutional weaknesses in governance. We present a simple dynamic model where weak governing institutions allow the rich to be more effective in appropriating a larger share of public education spending thereby preventing inequality reduction. The empirical part provides tentative support for this view, showing that the progressiveness of public education spending is related to the strength of governance.
\end{abstract}

JEL Classification Numbers: I2, H42, O11, O15, O17

Keywords: Public education, incidence bias, inequality, governance

Author(s) E-Mail Address: edablanorris@imf.org; grade@bgumail.bgu.ac.il

\footnotetext{
${ }^{1}$ Mark Gradstein is a professor at Ben Gurion University. The authors are grateful to Hamid Davoodi for sharing his dataset. We would also like to thank Andrew Feltenstein, Miguel Messmacher, Alexander Plekanov, Vladimir Kluyev, and participants at the INS seminar series for their valuable comments.
} 


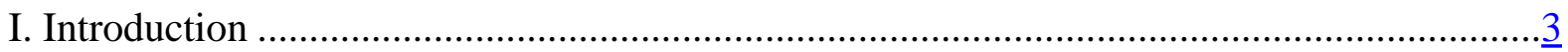

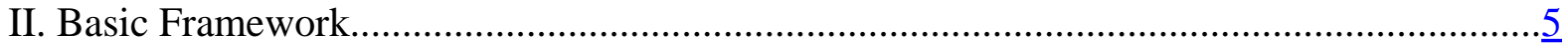

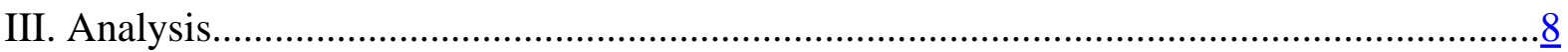

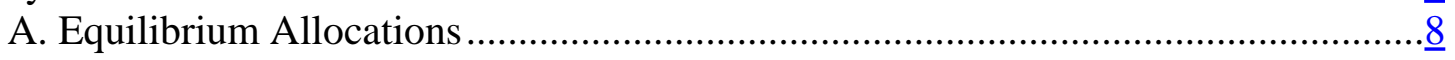

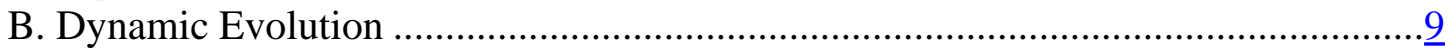

C. Comparison with Private Education..................................................................11

IV. Incidence Bias of Public Education: Evidence .......................................................13

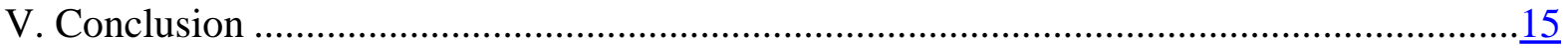

Tables

1. Summary Statistics and Correlations ....................................................................16

2. Bias in Public Education Spending (Q5/Q1) and Governance: Ordinary Least Squares .....17

3. Bias in Public Education Spending (Q5) and Governance: Ordinary Least Squares ...........18

4. Bias in Public Education Spending and Governance: IV Regressions .............................19

Figures

1. Bias in Public Education Spending and Good Governance...........................................20

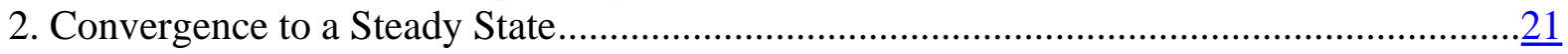

Appendices

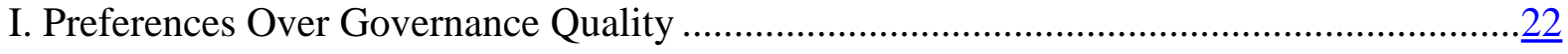

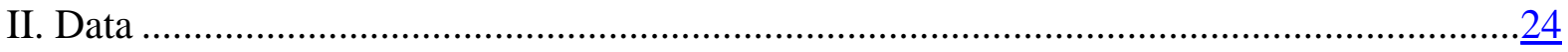

Appendix Table

1. Benefit Incidence of Public Spending on Education …...............................................

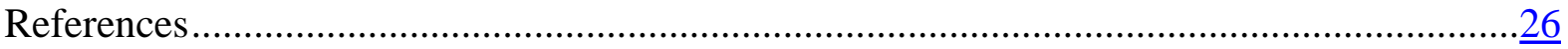




\section{INTRODUCTION}

Much public spending is carried out with redistributive goals in mind. Public provision of goods and services is commonly perceived as uniform and egalitarian and has often been defended as such on normative grounds. In fact, universal public provision has been viewed as the main vehicle for achieving equity goals in the economy, see Tawney (1952) for an influential articulation of this position, and most economic models treat such public programs; as supplying a uniform level of services see, for example, Meltzer and Richard (1981), in the context of income transfers, Epple and Romano (1996) in the health context, and — closer to this paper's focus, Doepke and de la Croix (2004a, 2004b) —in the context of public education.

The effectiveness of many of these programs in achieving redistributive goals through uniform provision, however, remains questionable. At the policymaking level, there has been growing awareness of their potential failure, especially in countries with weak institutionsdue to political capture, bureaucratic inefficiencies, etc. ${ }^{2}$ Consequently, the actual incidence of public spending is often skewed in favor of more influential population groups. In an important work, Le Grand (1982) documents this in many areas of public intervention in the United Kingdom, such as education, health, housing, and transportation, arguing that the middle class and the rich are its primary beneficiaries.

Pro-rich biases in the incidence of public spending can be even more significant in developing countries. Consider public spending on education, an example used throughout the paper. Children from poor households have much less access to schooling at progressively higher levels than children from richer families, and their attrition rates increase with the grade (see World Bank Development Report (2004) especially chapters 2 and 7). Birdsall (1997), for example, notes that spending on primary education in developing countries is small relative to spending on tertiary education-whose main beneficiaries are the rich; the problem is especially acute in Latin America and Africa, where income inequality in general is notoriously high. ${ }^{3}$ Likewise, schools' geographic location may have distributional consequences depending on the relative concentration of income groups in a particular area. Consequently, the distribution of public spending on education in the population is far from equal. For some countries, the incidence of public spending that accrues to the top quintile is three to four times larger than that received by the bottom quintile (World Bank 2001, 2004).

\footnotetext{
${ }^{2}$ Several recent studies, summarized in the World Bank Development Report (2004) have documented such failures in a variety of contexts; Esping-Anderson (1990) arguing from a cross country perspective, find significant differences across countries in the extent and the nature of public programs.

${ }^{3}$ In a cross-country framework, Hwang (2004) shows that the share of resources allocated to tertiary education is positively related to income inequality.
} 
Moreover, the unequal incidence bias is negatively correlated with the strength of governance in a country. Figure 1 is a striking illustration of the bivariate relationship between the two. In a cross section of 36 developing countries, the share of public education spending accruing to the wealthiest quintile relative to the poorest is negatively associated with an indicator of governance (see Section IV and the appendix for details on the data). In the figure, Malaysia (MYS) is the country with one of the lowest bias in public education spending; it also has the best quality of governance. Mozambique (MOZ) has a very high pro-rich bias in education spending, and also fairs very poorly in the enforcement of rule of law.

This paper's objective is to study the incidence bias of public education and its implications. To this end, we construct a simple dynamic model of public education spending designed to achieve egalitarian objectives. This spending, however, is subject to appropriation through rent seeking. Richer individuals, being less credit constrained, can spend more on rent seeking and, therefore, have an advantage in appropriating a larger share of public spending. ${ }^{4}$ Their ability to do so depends, in turn, on the prevailing governance quality: where quality of governance is higher, there is less room for such appropriation.

The theoretical framework implies that weak governance results in a higher level of rent seeking and a skewed incidence of public spending towards the rich. This, in turn, has dynamic implications in adversely affecting future income distribution and intertemporal mobility as well as impeding economic growth. Comparison with the private education system reveals that the support for public education also hinges on good governance.

One of the model's implications, the effect of governance quality on the incidence bias, is then empirically tested using a recently compiled cross country data set. The results are consistent with the model's prediction. Even after controlling for an economy's level of development and additional characteristics, measures of governance quality have a moderating effect on the incidence of pro-rich bias in public education spending. Moreover, this relationship is robust across various measures of governance quality and incidence bias.

This paper is related to recent studies that examine the growth and inequality effects of public education and its political sustainability, as in, for example, Gradstein and Justman (1997), Doepke and de la Croix (2004a), among others. Empirically, these issues have been emphasized in, for example, Barro (1991) and Gylfason and Zoega (2003). It differs from all this work, however, by examining the implications of differential access to public funds. ${ }^{5}$ As argued above, this assumption seems to be more realistic than the standard assumption of uniform access to public education. This paper is related to Bertocchi and Spagat (2004)

\footnotetext{
${ }^{4}$ The idea that in the presence of credit market imperfections, the initial distribution of wealth can affect economic outcomes has been examined by Galor and Zeira (1993) and Banerjee and Newman (1993) among others. Our paper explores a different channel, whereby imperfect capital markets allow the rich to more effectively engage in appropriation.

${ }^{5}$ See Gradstein (2004) for a static model of such differential access.
} 
who similarly pay attention to the lack of uniformity of public education albeit addressing a different aspect, namely, the joint evolution of comprehensive and vocational schooling; to $\mathrm{Su}$ (2004) who considers the allocation of public education funds across education levels, access to which differs by income; and to Doepke and de la Croix (2004b) where some households opt out of the public education system. The emphasis on rent seeking over public education funds and governance quality as its moderating factor differentiates our approach from the above mechanisms.

Also related is the literature on targeting, particularly its more recent ramifications that adopt apolitical economy perspective to understand the sources of the leakage of public funds to rich beneficiaries, see for example, Gelbach and Pritchett (2002) and Ravallion (1999). In these models, leakages occur to ensure political support for public programs by the rich, whereas here it is the direct consequence of rent seeking. The more important difference, however, is that our framework enables examination of the role of governance factors, which empirically are shown, to be a significant factor in shaping the distribution of public spending.

The rest of the paper is organized as follows. The model's presentation, in the next section, is followed by the equilibrium analysis and comparison with a private education system in Section III. Empirical implications are then studied in Section IV, and Section V concludes with brief remarks.

\section{BASIC FRAMEWORK}

Consider an economy populated by an infinite number of successive generations of households, indexed $i$, whose measure in each period is normalized to one operating over an infinite horizon. Each household consists of a parent and a child. The initial amount of household income is $y_{i 0}$, and income in period $t$ is $y_{i t}$. In each period, the households invest part of their income in the public provision of an investment good. This good can have the interpretation of physical infrastructure (a public good) or human capital investment through education (a publicly provided private good). For concreteness, we will stick with the latter interpretation and confine our attention to issues associated with public education finance and its distribution as the means to build human capital. This is mainly because of the belief expressed in recent growth theories that human capital is an important determinant of economic growth (see Barro (1991), Gylfason and Zoega (2003), Mankiw et al. (1992)).

Thus, public spending on education is assumed to be financed by a proportional income tax, whose rate is denoted $T$; the disposable income is then $y_{i t}(1-T)$. Assuming a balanced budget in each period, the aggregate (or, what is equivalently, the average) amount of spending on public education is $T Y_{t}$. We treat this tax as exogenous, showing below that all individuals will support the same tax rate in each period.

The disposable income is allocated between family consumption, $c_{i t}$, and individual investment made in an attempt to ensure a larger share of educational resources for one's offspring, $x_{i t+1}$. As will be seen below, this investment does not have any productive value; 
rather, it just affects the distribution of educational resources across the households. It can be interpreted, therefore, as rent seeking. ${ }^{6}$

Normalizing all prices to one, the budget constraint then is

$$
y_{i t}=c_{i t}+T y_{i t}+x_{i t+1}
$$

The shares of educational resources accruing to a household are then determined based on the individual efforts:

$$
S_{i t+1}=\frac{X_{i t+1}{ }^{1-Q_{t}}}{\int_{0}^{1} x_{j t+1}{ }^{1-Q_{t}} d j}
$$

where $Q_{t}, 0 \leq Q_{t} \leq 1$, is interpreted as the quality of governance in the economy. ${ }^{7}$ When $Q_{t}=1$, all households have an equal access to educational resources. This corresponds to the situation where the existing institutional and political arrangements preclude rent seeking with the resulting differential access to public education. In contrast, when $Q_{t}=0$, governance quality is low, and the access to public education depends to a large degree on households' rent seeking efforts to gain this access. We regard this parameter as exogenously given, but consider its endogenous determination in the appendix. The specification in (2) is an extension for an infinite population of the Tullock-contest rent seeking function, see Nitzan, 1994, for a survey and other applications.

An individual's production input is then $s_{i t+1} T Y_{t}{ }^{8}$ Thus, the intention of uniformity of public spending on education notwithstanding, households may be able to appropriate public funds to various degrees. Indeed, the assumption that credit markets are imperfect, embodied in equation (1), effectively will imply that richer households possess an advantage - whose

\footnotetext{
${ }^{6}$ For example, one can think about the allocation of public spending on education between comprehensive and vocational schooling as in Bertocchi and Spagat (2004); between different locations such as in urban versus rural areas; or between the different layers of education, such as primary and secondary as opposed to tertiary education as in Su (2004).

${ }^{7}$ When there is no rent seeking, each household gets and equal amount $T Y_{t}$ of public funds.

${ }^{8}$ Other production inputs are disregarded for simplicity. Perhaps more importantly, note that private spending on education is ignored here - not because it is not important (on the contrary, it can be significant, especially in developing countries), but because its existence would likely exacerbate the results by skewing the distribution of educational resources even more - see Fereira (2001). This also helps us to keep focus on the main point, which is the bias in the distribution of public spending.
} 
extent will be assumed to be politically determined - in appropriating a larger portion of public educational resources than poor households do. ${ }^{9}$

The children differ in their production capabilities to make use of their educational endowment. These differences may have to do with innate abilities, access to technological knowledge, social and family background or differences in previously acquired skills. We let $A_{i t}$ denote the production capability of individual $i$. Assuming a variation of the CobbDouglas technology, the amount of next-period income generated by household $i$ is

$$
y_{i t+1}=A_{i t+1}\left(s_{i t+1} T Y_{t}\right)^{\alpha}, 0<\alpha<1
$$

A person's production capability depends on the level of technology to which everyone has access, $A$, and on individual ability, $a_{i t}:{ }^{10}$

$$
A_{i t}=A a_{i t}^{\gamma}
$$

where the parameter $\gamma, 0 \leq \gamma \leq 1$, represents the relative importance of individual ability.

The generated income is bequeathed to the child. Preferences are assumed to be identical across individuals. In particular, all parents are assumed to derive utility from household consumption as well as from a child's anticipated income. This "warm glow" bequest motive is simple enough to allow a closed form analysis of the economy's intertemporal evolution. Assuming for simplicity logarithmic preferences and ignoring discounting, the households will be interested in maximizing the expected utility:

$$
U_{i t}\left(c_{i t}, y_{i t+1}\right)=\ln \left(c_{i t}\right)+\ln \left(y_{i t+1}\right)
$$

Introducing discounting does not change any of the model's substantive conclusions. In contrast, as will become clearer later, the logarithmic specification in conjunction with the assumed production technology implies a lack of complementarity between personal traits and individual inputs. While these assumptions are made to simplify the dynamic analysis,

\footnotetext{
${ }^{9}$ Note that the assumption that private spending incurred to gain access to educational resources is all rent seeking is extreme. Admission to public institutions of learning (schools, colleges, universities, etc.), as well as allocation of scholarships, are frequently determined by aptitude tests, which do have social value. Yet, even this aspect of the allocation of educational resources may entail rent seeking to the extent that these tests are imprecise and preparation for them improves performance.

10 The level of technology is assumed constant over time primarily for notational brevity; as long as it is exogenous, this is immaterial for the results.
} 
they still allow for an interesting interaction between personal characteristics on the one hand and individual and collective decisions on the other hand.

The allocation decisions in the economy are made in each period by the parents, and the equilibrium consists of a sequence of such mutually consistent decisions.

\section{ANALYSIS}

\section{A. Equilibrium Allocations}

We begin the analysis with the individual allocation decisions. Maximization of the utility function (5) subject to (1)-(4) yields:

$$
\begin{aligned}
& x_{i t+1}=\alpha\left(1-Q_{t}\right) y_{i t}(1-T) /\left(1+\alpha\left(1-Q_{t}\right)\right), c_{i t}=y_{i t}(1-T) /\left(1+\alpha\left(1-Q_{t}\right)\right), \text { and } \\
& s_{i t+1}=y_{i t}{ }^{1-Q_{t}} / \int_{0}^{1} y_{j t}{ }^{1-Q_{t}} d j
\end{aligned}
$$

so that, in particular, individual rent seeking efforts decrease with the level of governance quality $Q_{t}$.

Substituting the above values into (3), while using (4), and then into (5) respectively we obtain:

$$
y_{i t+1}=A_{i t+1} S_{i t+1} T Y_{t}=A a_{i t+1}^{\gamma}\left[y_{i t}{ }^{1-Q_{t}} T Y_{t} / \int_{0}^{1}\left(y_{j t}\right)^{1-Q} d j\right]^{\alpha}
$$

And

$$
U_{i t}=\ln \left[y_{i t}(1-T) /\left(1+\alpha\left(1-Q_{t}\right)\right)\right]+\ln \left\{A a_{i t+1}{ }^{\gamma}\left[y_{i t}{ }^{1-Q_{t}} T Y_{t} / \int_{0}^{1}\left(y_{j t}\right)^{1-Q_{t}} d j\right]^{\alpha}\right\}
$$

From (7), there are two sources of income differences in the next generation. One is the exogenous differences in individual abilities, and the other is current income differences; moreover, the elasticity of the next-period inequality with respect to the current one is an increasing function of the governance quality. Also note that differentiation of the indirect utility function in (8) with respect to the tax rate implies that all individuals in all periods unanimously agree on their preferred tax rate, $\mathrm{T}=\alpha /(1+\alpha)$.

For the purposes of explicit characterization of economy's dynamic evolution, we suppose that $\ln \left(y_{i 0}\right)$ is distributed normally with mean $\mu_{0}$ and variance $\sigma_{0}{ }^{2}$, and that in each period abilities are lognormally distributed in the population, with the parameters, say, 0 and 1; we assume that they are not correlated. This will imply that abilities are not correlated with 
incomes in each period and intertemporally. Equation (4) implies then that in subsequent periods, $\ln \left(A_{i t}\right)$ is also normally distributed, with the parameters $\ln (A)$ and $\gamma^{2}$, and equation (7) implies that $\ln \left(y_{i t}\right)$ is normally distributed as well; we let $\mu_{\mathrm{t}}$ and $\sigma_{\mathrm{t}}^{2}$ respectively denote its mean and the variance respectively.

Taking logarithms of the shares in (6) we then obtain:

$$
\ln \left(s_{i t+1}\right)=\left(1-Q_{t}\right) \ln \left(y_{i t}\right)-\ln \left[\int_{0}^{1}\left(y_{j t}\right)^{1-Q_{t}} d j\right]
$$

and, in particular, it follows that $\ln \left(s_{i t+1}\right)$ has the variance of

$$
\text { Bias }=\left(1-\mathrm{Q}_{\mathrm{t}}\right)^{2} \sigma_{\mathrm{t}}^{2}
$$

This variance can be perceived as a measure of pro-rich incidence bias, and it is clear that the incidence bias decreases with the strength of governance and increases with income inequality thus leading to

Proposition 1. Stronger governance and lower level of current income inequality imply a smaller incidence bias.

An indirect support for the relationship between inequality and incidence bias is lent by a recent paper by Hwang (2004), where is it found that the share of education resources spent on tertiary schooling is positively related to asset inequality. The indicated relationship between governance and incidence bias will be explicitly tested below.

\section{B. Dynamic Evolution}

Substituting (4) and the tax rate into (7) and taking the logarithms we obtain:

$$
\ln \left(y_{i t+1}\right)=\ln (A)+\gamma \ln \left(a_{i t+1}\right)+\alpha\left(1-Q_{t}\right) \ln \left(y_{i t}\right)+\alpha \ln \left(T Y_{t}\right)-\alpha \ln \left[\int_{0}^{1}\left(y_{j t}\right)^{1-Q_{t}} d j\right]
$$

It follows that $\ln \left(y_{i t+1}\right)$ has the mean of

$$
\begin{aligned}
& \mu_{t+1}=\ln A+\alpha\left(1-\mathrm{Q}_{\mathrm{t}}\right) \mu_{t}+\alpha\left(\mu_{t}+\sigma_{\mathrm{t}}^{2} / 2\right)+\alpha \ln (T)-\alpha\left(\left(1-\mathrm{Q}_{\mathrm{t}}\right) \mu_{t}+\left(1-\mathrm{Q}_{\mathrm{t}}\right)^{2} \sigma_{\mathrm{t}}^{2} / 2\right)= \\
& \ln A+\alpha\left(\mu_{t}+\sigma_{\mathrm{t}}^{2} / 2\right)+\alpha \ln (T)-\alpha\left(1-\mathrm{Q}_{\mathrm{t}}\right)^{2} \sigma_{\mathrm{t}}^{2} / 2
\end{aligned}
$$

and the variance of 


$$
\sigma_{\mathrm{t}+1}{ }^{2}=\gamma^{2}+\left(\alpha\left(1-\mathrm{Q}_{\mathrm{t}}\right)\right)^{2} \sigma_{\mathrm{t}}^{2}=\gamma^{2}+\alpha^{2} \text { Bias }
$$

which decreases with the quality of governance, or alternatively, increases with the incidence bias. Moreover, given a constant level of governance, say $Q$, it converges to a steady state, $\sigma^{2^{*}}=\gamma^{2} /\left[1-(\alpha(1-Q))^{2}\right]$, at which point inequality is again a decreasing function of institutional quality (see Figure 2). Note that, in the presence of heterogeneity in individual abilities, income heterogeneity is preserved in the steady state, despite the stipulated decreasing-returns-to-scale technology.

Substituting from (11) and (12) we can also calculate a measure of social mobility across generations as the complement to the intertemporal correlation between (the logarithms) of incomes,

$$
\begin{aligned}
& 1-\operatorname{Cov}\left(\ln \left(y_{i t+1}\right), \ln \left(y_{i t}\right)\right) / \sigma_{t+1} \sigma_{t}= \\
& 1-\frac{\operatorname{Exp}\left(\ln y_{i t+1}-\mu_{t+1}\right)\left(\ln y_{i t}-\mu_{t}\right)}{\sigma_{t+1} \sigma_{t}}= \\
& 1-\frac{\operatorname{Exp}\left[\left(\gamma \ln a_{i t+1}\right)\left(\ln y_{i t}-\mu_{t}\right)\right]+\alpha\left(1-Q_{t}\right) \operatorname{Exp}\left(\ln y_{i t}-\mu_{t}\right)^{2}}{\sigma_{t+1} \sigma_{t}}= \\
& 1-\frac{\alpha\left(1-Q_{t}\right) \sigma_{t}}{\sigma_{t+1}}=1-\left\{1 /\left[\left(\gamma / \alpha\left(1-Q_{t}\right) \sigma_{t}\right)^{2}+1\right\}^{1 / 2}\right.
\end{aligned}
$$

where $\operatorname{Exp}$ denotes the expectation parameter and we have used the assumption $\operatorname{Exp}\left(\ln a_{i t+1}\right)$ $=0$ and the implied independence between abilities and incomes across time, so that $\operatorname{Exp}[\gamma$ $\left.\ln a_{i t+1}\left(\ln y_{i t}-\mu_{\tau}\right)\right]=\gamma\left[\operatorname{Exp}\left(\ln a_{i t+1}\right) \operatorname{Exp}\left(\ln y_{i t}\right)-\mu_{\mathrm{t}} \operatorname{Exp}\left(\ln a_{i t+1}\right)\right]=0$. Since (14) increases in $Q_{t}$, this implies that higher governance quality enhances social mobility.

The above derivations also allow us to calculate the logarithm of the average income growth rate,

$$
\begin{aligned}
& g_{t+1}=\ln \left(Y_{t+1} / Y_{t}\right)= \\
& \ln A+\alpha\left(\mu_{t}+\sigma_{\mathrm{t}}^{2} / 2\right)+\alpha \ln (T)-\alpha\left(1-\mathrm{Q}_{\mathrm{t}}\right)^{2} \sigma_{\mathrm{t}}^{2} / 2+\left[\gamma^{2}+\left(\alpha\left(1-\mathrm{Q}_{\mathrm{t}}\right)\right)^{2} \sigma_{\mathrm{t}}^{2}\right] / 2-\left[\mu_{t}+\sigma_{\mathrm{t}}^{2} / 2\right]= \\
& \ln A+(\alpha-1)\left(\mu_{t}+\sigma_{\mathrm{t}}^{2} / 2\right)+\alpha \ln (T)+\gamma^{2} / 2+\alpha(\alpha-1)\left(1-\mathrm{Q}_{\mathrm{t}}\right)^{2} \sigma_{\mathrm{t}}^{2} / 2
\end{aligned}
$$

and differentiation reveals that next-period growth increases with governance quality and decreases with the incidence bias.

From (12a) we obtain that, for a constant quality level, the parameter $\mu$ also converges: $\mu^{*}=\left[\ln A+\alpha \ln (T)+\alpha\left(1-(1-\mathrm{Q})^{2}\right) \sigma^{2^{*}} / 2\right] /(1-\alpha)$, implying that the growth rate converges to a steady state - which, again, is an increasing function of the governance quality.

Summarizing these points, 
Proposition 2. A better governance quality in period $t$ reduces income inequality in the next period and in the steady state, as well as increases intergenerational mobility and enhances growth.

A better quality of governance reduces the marginal benefit from rent seeking, implying, in turn, a more equal distribution of public funds (see Proposition 1). Since public education is the input for production, this leads to a more egalitarian distribution of income in the children's generation and to larger social mobility. Note that the positive growth effect here is not a consequence of reduced rent seeking, as the latter does not effect the amount of resources devoted to education. Instead, diminishing marginal returns to schooling imply that a more egalitarian distribution of education resources is beneficial for growth.

The detrimental growth effect of poor governance has been documented in recent literature, see, for example, Knack and Keefer (1995) and Rodrik et al. (2002). Additionally, Chong and Gradstein (2004) present evidence on its adverse effect on income inequality. More specifically, Castello and Domenech (2002) note that the reduction in education inequality in the period 1960-2000 has been a significant factor in spurring up subsequent growth.

While the above analysis treats governance quality as exogenously given, the appendix presents its endogenization through voting, also indicating the possibility of multiple steady states, whose realization depends on initial conditions.

\section{Comparison with Private Education}

This sub-section deals with the comparison between two alternative education regimes, public education as above, and the private education regime. It is related to some recent literature, see Gradstein and Justman, 1997, Doepke and de la Croix, 2004a, and references therein. In particular, this literature points out the redistributive nature of public education, which implies that the preference toward public education is stronger among the poor. Our contribution here is to identify governance quality as an additional factor that plays an important role in the comparison between the two regimes.

Thus, consider now an alternative private education regime, whereby the households allocate their income between consumption and education spending,

$$
y_{i t}=c_{i t}+e_{i t+1}
$$

and education spending generates income,

$$
y_{i t+1}=A_{i t+1}\left(e_{i t+1}\right)^{\alpha}, 0<\alpha<1
$$

The abilities and the utilities are as defined in (4) and (5).

Utility maximization then yields: 


$$
e_{i t+1}=\alpha y_{i t} /(1+\alpha), \quad c_{i t}=y_{i t} /(1+\alpha)
$$

and substitutions yield future income:

$$
y_{i t+1}=A a_{i t+1}^{\gamma}\left[\alpha y_{i t} /(1+\alpha)\right]^{\alpha}
$$

and household's utility level, designated $R$ :

$$
\begin{aligned}
& R_{i t}=\ln \left[y_{i t} /(1+\alpha)\right]+\ln \left\{A a_{i t+1}{ }^{\gamma}\left[\alpha y_{i t} /(1+\alpha)\right]^{\alpha}\right\}= \\
& \ln \left[y_{i t} /(1+\alpha)\right]+\ln (A)+\gamma \ln \left(a_{i t+1}\right)+\alpha \ln \left(y_{i t}\right)+\alpha \ln [\alpha /(1+\alpha)]
\end{aligned}
$$

Note that the amount of education, from (16), is directly proportional to household's income. In contrast, in the public education case, this relationship is mediated through governance quality. Only if this quality equals zero $(\mathrm{Q}=0)$, is education quantity proportional to income, otherwise, the relationship is subject to diminishing returns to scale, whose magnitude depends on governance quality, so that doubling income results in capturing less than twice of public education budget. This will have important consequences for the comparison below.

From (8), using the fact that the tax rate of $T=\alpha /(1+\alpha)$ enjoys unanimous support, we re-write the utility level under public education as

$$
\begin{aligned}
& U_{i t}=\ln \left[y_{i t}(1-T) /\left(1+\alpha\left(1-\mathrm{Q}_{t}\right)\right)\right]+ \\
& \ln (A)+\gamma \ln \left(a_{i t+1}\right)+\alpha\left(1-\mathrm{Q}_{t}\right) \ln \left(y_{i t}\right)+\alpha \ln \left(T Y_{t}\right)-\alpha \ln \left[\int_{0}^{1}\left(y_{j t}\right)^{1-Q_{t}} d j\right]= \\
& \ln \left[\alpha y_{i t} /(1+\alpha)\left(1+\alpha\left(1-\mathrm{Q}_{t}\right)\right)\right]+ \\
& \ln (A)+\gamma \ln \left(a_{i t+1}\right)+\alpha\left(1-\mathrm{Q}_{t}\right) \ln \left(y_{i t}\right)+\alpha \ln \left(\alpha Y_{t} /(1+\alpha)\right)-\alpha\left(\left(1-\mathrm{Q}_{t}\right) \mu_{t}+\left(1-\mathrm{Q}_{t}\right)^{2}\right. \\
& \left.\sigma_{\mathrm{t}}^{2} / 2\right)
\end{aligned}
$$

The utility differential is then

$$
U_{i t}-R_{i t}=\ln \left[1 /\left(1+\alpha\left(1-\mathrm{Q}_{t}\right)\right)\right]-\alpha \mathrm{Q}_{\mathrm{t}} \ln \left(y_{i t}\right)+\alpha \mathrm{Q}_{\mathrm{t}} \mu_{\mathrm{t}}+\alpha \mathrm{Q}_{\mathrm{t}}\left(2-\mathrm{Q}_{\mathrm{t}}\right) \sigma_{\mathrm{t}}^{2} / 2
$$

Differentiation reveals that richer households are more in favor of the private education regime. For the median voter, the utility differential, $\ln \left[1 /\left(1+\alpha\left(1-\mathrm{Q}_{t}\right)\right)\right]+\alpha \mathrm{Q}_{\mathrm{t}}\left(2-\mathrm{Q}_{\mathrm{t}}\right) \sigma_{\mathrm{t}}^{2} / 2$, increases in governance quality, is negative for $\mathrm{Q}_{\mathrm{t}}=0$ and positive for $\mathrm{Q}_{\mathrm{t}}=1$, indicating that the majority support for public education hinges upon good governance quality.

Some earlier empirical research that studied the determinants of private schooling identified the level of development and income inequality as important factors in this regard, see James, 
1993, Toma, 1996. Our analysis suggests that governance quality may constitute yet another such factor, which may inform further empirical analysis.

\section{InCIDEnCE Bias of Public Education: Evidence}

In this section, we use a new cross-country data set compiled by Davoodi et. al (2003) on the benefit incidence of public education spending for 36 developing and transition countries in the 1990s to test the empirical validity of Proposition 1 (See appendix for details and complete list of countries). In particular, we test the hypothesis that a pro-rich bias in public education spending is higher, the lower the quality of governance by considering the following specification:

$$
\text { Bias }_{i}=\alpha+\beta_{1} \text { Gini }_{i}+\beta_{2} \text { Inst }_{i}+\beta_{3} X+\varepsilon_{i}
$$

where Bias $_{i}$ is the relevant measure of bias in public education spending in country $i$, Gini $i_{i}$ is a measure of gross income inequality, Inst $t_{i}$ is our measure of governance quality, and $X$ is a vector of additional variables to control for other factors that might affect the incidence of education spending for the rich relative to the poor.

We use two alternative measures of the extent of pro-rich bias in public education spending, the ratio of total education spending accruing to the wealthiest quintile relative to the poorest quintile $(Q 5 / Q 1)$, and the share of public education benefits accruing to wealthiest income quintile (Q5). As can be seen from Table A1, there is wide variation in the extent of pro-poor bias across countries. Chile is the country with the lowest bias in public education spending, with less than 5 percent of the benefits accruing to the wealthiest quintile relative to over 40 percent by the poor, and a Bias value of 0.1 ; Nepal has the highest bias in public education spending, with more than 46 percent accruing to the wealthiest quintile, relative to 11 percent to the poorest, with a Bias value of 4.4.

We consider three measures of governance quality. First, we use a simple average of the index of civil liberties and political rights, the Gastil index, as a proxy for political governance in a country. Second, we use two governance indicators developed by Kaufmann et al. (1999), namely regulatory quality, as a measure of the capacity of the government to effectively formulate and implement sound policies, and rule of law, as a measure of the respect of citizens and the state for institutions that govern economic and social interactions between them. All governance variables are rescaled between 0 and 1 , with higher values denoting better governance quality.

To control for other potential determinants of a pro-rich bias in spending, we run equation (16) including other controls one at a time. First, we control for the possibility that differences in economic development influence the effectiveness of targeting resources to the poor by including the real per capita GDP (Igdp) averaged over the 1980s. To control for the access of the poor to financial markets, we use the ratio of private sector credit to GDP (Credit) as a measure of private sector development. We expect that a less developed financial sector make it difficult for the poor to access credit and accumulate capital, thereby, preserving an existing uneven distribution of wealth. Other authors have stressed that 
political participation and the ability of the elite to influence spending depend on the educational level (Bourguignion and Verdier (2000)). We control for this effect by including a measure of the average educational attainment of the population aged 25 and over in 1990 (Educ). ${ }^{11}$ Table 1 includes descriptive statistics for all the variables included in the regressions.

Tables 2 and 3 present the OLS estimates of equation (16) for the two measures of pro-rich bias in public spending. Both tables confirm that the theoretical predictions in Proposition 1 are borne out by the data. The coefficient on the governance indicators is consistently negative and statistically significant at the 1 percent level for all indicators of governance and across both measures of bias. This implies that good governance is associated with a lower pro-rich bias in public education spending. Columns (2), (6) and (10) in both Tables 2 and 3 include Gini coefficients in the regressions. The Gini coefficient often enter with a positive sign but it is not statistically significant in any specification.

The inclusion of additional variables does not overturn any of the qualitative results, although the governance measures are now significant at 5 percent levels for some specifications. There is some evidence to suggest that wealthier countries have a lower pro-rich bias in prorich bias in spending, but the coefficients are not consistently significant (see columns 3, 7, and 11 in Tables 2 and 3). The relationship between educational attainment in a country and the extent of pro-rich bias in public education, while of the expected sign in most regressions, is only statistically significant when the share of public education benefits accruing to the wealthiest quintile (Q5) is the relevant measure of bias (columns 4 and 8 in Table 3). Greater financial sector development, which is a proxy for credit market imperfections, is associated with a lower pro-rich bias in public spending when the gastil index is used as the relevant measure of governance (column 3 in Table 1), but is not of the expected sign or statistically significant across other measures of bias and governance.

Estimating equation (16) with Ordinary Least Squares (OLS) introduces several biases into the model. One obvious source of bias is omitted variables and simultaneity bias. To at least partly alleviate these concerns, we use IV estimation to extract the exogenous component of the indicators of governance. We adopt a conservative approach by treating income inequality and other controls as exogenous. This strategy typically creates an upward bias in the effects of these controls, and a potential downward bias in the effect of the governance indicators on pro-rich spending bias.

As instruments we use the distance from the equator (Lat) and the fraction of the population speaking English and European languages. We are unable to reject the null hypothesis that our instruments are uncorrelated with the error term, suggesting their validity (see p value of Hansen J-Statistic in Table 4). This indicates that the instrumental variables are not related to

${ }^{11}$ We also controlled for the possibility of an urban bias in education spending, by including a measure of rural population in total. This was not found to be significant in any of the regressions, possibly due to the high collinearlity between this variable and initial GDP per capita. Results are available from the authors upon request. 
a pro-rich bias in education spending beyond their influence through indicators of governance or other explanatory variables.

Good governance results in a lower pro-rich bias in public education spending , as indicated by Table 4 . We find that, consistent with our theoretical predictions, the coefficients on the governance measures are negative and statistically significant across all measures and specifications. However, the coefficients on the governance measure are now only significant at the 5 and 10 percent levels. After controlling for endogeneity of the governance variables, many of the coefficients on the other control variables are not consistently significant.

\section{Conclusion}

Much theoretical thinking about public education has portrayed its incidence as progressive, assuming in particular that its benefits accrue uniformly to different income groups. On the other hand, it has frequently been claimed that the incidence of public spending on education, especially in developing countries, is biased in favor of the rich. This paper argues that the extent of such bias is ultimately determined by the prevailing quality of governance. It then examines the dynamic implications of such bias for income inequality, social mobility, and growth. It is shown that weak governance leads to intensified rent seeking over public education funds, increasing inequality, reducing social mobility, and slowing growth.

The relationship between governance quality and incidence bias is then empirically tested using a cross-country data set. The analysis reveals a robust effect of the former: both in the OLS and in the IV estimations, governance quality is a robust predictor of the incidence bias, after controlling for additional factors associated with the economy's development and background characteristics.

Many issues are left for further research. The most important one is the empirical study of the inequality and growth implications of the incidence bias indicated in the analytical framework. For this, however, a panel data set would be needed, and the currently limited coverage of the incidence bias across time prevents such analysis. Also, it would be interesting to extend the above analysis to study incidence bias in other areas such as health, welfare spending, infrastructure, etc. In particular, an interesting question is whether governance quality is an important factor in these other areas as well. 
Table 1: Summary Statistics and Correlations

\begin{tabular}{|c|c|c|c|c|c|c|c|c|c|}
\hline & Q5/Q1 & Q5 & Regulatory quality & Rule of Law & Gastil & Gini & $I G D P$ & Educ & Credit \\
\hline Mean & 1.76 & 23.64 & 0.53 & 0.46 & 0.59 & 44.11 & 2611.63 & 4.85 & 24.25 \\
\hline Standard deviation & 1.28 & 9.49 & 0.09 & 0.10 & 0.23 & 9.94 & 1675.14 & 2.32 & 17.90 \\
\hline Maximum & 5.02 & 46.00 & 0.75 & 0.74 & 1 & 63.00 & 6614.40 & 9.26 & 79.04 \\
\hline Minimum & 0.11 & 4.60 & 0.38 & 0.28 & 0 & 24.53 & 508.70 & 0.84 & 3.18 \\
\hline & Q5/Q1 & Q5 & Regulatory quality & Rule of Law & Gastil & Gini & $I G D P$ & Educ & Credit \\
\hline Q5/Q1 & 1 & & & & & & & & \\
\hline Q5 & 0.92 & 1 & & & & & & & \\
\hline Regulatory quality & -0.61 & -0.61 & 1 & & & & & & \\
\hline Rule of Law & -0.50 & -0.52 & 0.75 & 1 & & & & & \\
\hline Gastil & -0.45 & -0.47 & 0.46 & 0.32 & 1 & & & & \\
\hline Gini & -0.18 & -0.14 & 0.40 & 0.29 & 0.29 & 1 & & & \\
\hline$I G D P$ & -0.38 & -0.44 & 0.48 & 0.37 & 0.33 & 0.10 & 1 & & \\
\hline Educ & -0.31 & -0.51 & 0.39 & 0.37 & 0.29 & -0.06 & 0.62 & 1 & \\
\hline Credit & -0.24 & -0.19 & 0.45 & 0.51 & 0.03 & 0.33 & 0.15 & 0.01 & 1 \\
\hline
\end{tabular}


Table 2: Bias in Public Education Spending (Q5/Q1) and Governance: Ordinary Least Squares

\begin{tabular}{|c|c|c|c|c|c|c|c|c|c|c|c|c|}
\hline \multirow{3}{*}{ Institutional Variable } & \multicolumn{12}{|c|}{ Dependent variable is Ratio of Benefits Accruing to Wealthiest Quintile Relative to Poorest (Q5/Q1) } \\
\hline & \multicolumn{4}{|c|}{ Gastil } & \multicolumn{4}{|c|}{ Regulatory Quality } & \multicolumn{4}{|c|}{ Rule of Law } \\
\hline & $(1)$ & $(2)$ & $(3)$ & (4) & (5) & $(6)$ & $(7)$ & (8) & (9) & $(10)$ & $(11)$ & $(12)$ \\
\hline Inst & $\begin{array}{c}2.447 \\
(0.557)^{* * *}\end{array}$ & $\begin{array}{l}2.359 \\
(0.635)^{* * *}\end{array}$ & $\begin{array}{l}1.902 \\
(0.804)^{* *}\end{array}$ & $\begin{array}{l}2.073 \\
(0.877)^{* *}\end{array}$ & $\begin{array}{c}8.616 \\
(1.656)^{* * *}\end{array}$ & $\begin{array}{l}9.054 \\
(1.989) * * *\end{array}$ & $\begin{array}{l}8.346 \\
(2.056) * * *\end{array}$ & $\begin{array}{l}8.411 \\
(2.300)^{* * *}\end{array}$ & $\begin{array}{c}6.212 \\
(1.492)^{* * *}\end{array}$ & $\begin{array}{l}6.015 \\
(1.618)^{* * *}\end{array}$ & $\begin{array}{l}5.027 \\
(1.609) * * *\end{array}$ & $\begin{array}{l}5.049 \\
(2.020) * *\end{array}$ \\
\hline Gini & & $\begin{array}{l}-0.721 \\
(1.566)\end{array}$ & $\begin{array}{l}-0.698 \\
(1.649)\end{array}$ & $\begin{array}{l}0.212 \\
(1.934)\end{array}$ & & $\begin{array}{l}1.005 \\
(1.875)\end{array}$ & $\begin{array}{l}0.869 \\
(1.917)\end{array}$ & $\begin{array}{l}0.791 \\
(1.963)\end{array}$ & & $\begin{array}{l}-0.934 \\
(1.84)\end{array}$ & $\begin{array}{l}-0.882 \\
(1.899)\end{array}$ & $\begin{array}{l}-1.024 \\
(1.84)\end{array}$ \\
\hline $\operatorname{Igdp}$ & & & $\begin{array}{l}-0.02 \\
(0.012)\end{array}$ & $\begin{array}{l}-0.012 \\
(0.012)\end{array}$ & & & $\begin{array}{l}-0.007 \\
(0.01)\end{array}$ & $\begin{array}{l}-0.007 \\
(0.014)\end{array}$ & & & $\begin{array}{l}-0.017 \\
(0.010)^{*}\end{array}$ & $\begin{array}{l}-0.015 \\
(0.015)\end{array}$ \\
\hline Credit & & & & $\begin{array}{l}-1.669 \\
(0.871)^{*}\end{array}$ & & & & $\begin{array}{l}0.135 \\
(0.823)\end{array}$ & & & & $\begin{array}{l}0.147 \\
(0.906)\end{array}$ \\
\hline Educ & & & & $\begin{array}{l}-0.052 \\
(0.125)\end{array}$ & & & & $\begin{array}{l}-0.008 \\
(0.123)\end{array}$ & & & & $\begin{array}{l}-0.023 \\
(0.149)\end{array}$ \\
\hline Observations & 36 & 36 & 36 & 36 & 36 & 36 & 36 & 36 & 36 & 36 & 36 & 36 \\
\hline Adjusted R-squared & 0.18 & 0.17 & 0.19 & 0.20 & 0.36 & 0.34 & 0.34 & 0.29 & 0.23 & 0.21 & 0.23 & 0.18 \\
\hline
\end{tabular}

Robust standard errors in parentheses; All regressions include constant term

* significant at $10 \%$; ** significant at $5 \%$; *** significant at $1 \%$ 
Table 3: Bias in Public Education Spending (Q5 ) and Governance: Ordinary Least Squares

Dependent variable is Percent of Benefits Accruing to Wealthiest Quintile (Q5)

\begin{tabular}{|c|c|c|c|c|c|c|c|c|c|c|c|c|}
\hline \multirow[t]{2}{*}{ Institutional Variable } & \multicolumn{4}{|c|}{ Gastil } & \multicolumn{4}{|c|}{ Regulatory Quality } & \multicolumn{4}{|c|}{ Rule of Law } \\
\hline & (1) & (2) & (3) & (4) & (5) & (6) & $(7)$ & (8) & (9) & $(10)$ & $(11)$ & -12 \\
\hline Inst & $\begin{array}{c}19.222 \\
(4.452)^{* * *}\end{array}$ & $\begin{array}{c}19.139 \\
(4.973)^{* * *}\end{array}$ & $\begin{array}{c}14.924 \\
(6.048)^{* *}\end{array}$ & $\begin{array}{c}14.233 \\
(5.897)^{* *}\end{array}$ & $\begin{array}{c}63.462 \\
(11.498)^{* * *}\end{array}$ & $\begin{array}{c}68.48 \\
(13.592)^{* * *}\end{array}$ & $\begin{array}{c}58.663 \\
(13.892)^{* * *}\end{array}$ & $\begin{array}{c}53.858 \\
(16.599) * * *\end{array}$ & $\begin{array}{c}47.609 \\
(10.839)^{* * *}\end{array}$ & $\begin{array}{c}47.013 \\
(11.363)^{* * *}\end{array}$ & $\begin{array}{c}37.347 \\
(11.658)^{* * *}\end{array}$ & $\begin{array}{c}34.013 \\
(14.073)^{* *}\end{array}$ \\
\hline Gini & & $\begin{array}{c}-0.685 \\
(13.399)\end{array}$ & $\begin{array}{c}-0.472 \\
(14.458)\end{array}$ & $\begin{array}{c}0.456 \\
(15.236)\end{array}$ & & $\begin{array}{c}11.491 \\
(14.654)\end{array}$ & $\begin{array}{c}9.599 \\
(15.669)\end{array}$ & $\begin{array}{c}3.411 \\
(15.036)\end{array}$ & & $\begin{array}{c}-2.832 \\
(15.395)\end{array}$ & $\begin{array}{c}-2.322 \\
(15.727)\end{array}$ & $\begin{array}{c}-8.084 \\
(14.426)\end{array}$ \\
\hline $\operatorname{Igdp}$ & & & $\begin{array}{c}-0.181 \\
(0.083)^{* *}\end{array}$ & $\begin{array}{l}-0.042 \\
(0.073)\end{array}$ & & & $\begin{array}{l}-0.101 \\
(0.062)\end{array}$ & $\begin{array}{l}-0.009 \\
(0.092)\end{array}$ & & & $\begin{array}{c}-0.162 \\
(0.060)^{* *}\end{array}$ & $\begin{array}{c}-0.06 \\
(0.091)\end{array}$ \\
\hline Credit & & & & $\begin{array}{l}-9.553 \\
(6.435)\end{array}$ & & & & $\begin{array}{c}2.21 \\
(7.569)\end{array}$ & & & & $\begin{array}{c}2.737 \\
(7.047)\end{array}$ \\
\hline Educ & & & & $\begin{array}{c}-1.489 \\
(0.701)^{* *}\end{array}$ & & & & $\begin{array}{c}-1.225 \\
(0.719)^{*}\end{array}$ & & & & $\begin{array}{l}-1.296 \\
(0.848)\end{array}$ \\
\hline Observations & 36 & 36 & 36 & 36 & 36 & 36 & 36 & 36 & 36 & 36 & 36 & 36 \\
\hline Adjusted R-squared & 0.20 & 0.18 & 0.25 & 0.32 & 0.35 & 0.35 & 0.35 & 0.37 & 0.25 & 0.23 & 0.28 & 0.30 \\
\hline
\end{tabular}

Robust standard errors in parentheses; All regressions include constant term

* significant at $10 \%$; ** significant at $5 \%$; *** significant at $1 \%$ 
Table 4: Bias in Public Education Spending and Governance: IV Regressions

\begin{tabular}{|c|c|c|c|c|c|c|}
\hline Dependent Variable & & Q5/Q1 & & & Q5 & \\
\hline Institutional Variable & Gastil & Regulatory quality & Rule of Law & Gastil & Regulatory quality & Rule of Law \\
\hline Inst & $\begin{array}{c}-2.824 \\
(1.374)^{* *}\end{array}$ & $\begin{array}{c}-11.679 \\
(4.653)^{* *}\end{array}$ & $\begin{array}{c}-13.346 \\
(5.293)^{* *}\end{array}$ & $\begin{array}{c}-20.624 \\
(11.951)^{*}\end{array}$ & $\begin{array}{c}-87.061 \\
(36.479)^{* *}\end{array}$ & $\begin{array}{c}-74.927 \\
(40.076)^{*}\end{array}$ \\
\hline Gini & $\begin{array}{c}0.798 \\
(1.989)\end{array}$ & $\begin{array}{c}1.644 \\
(2.217)\end{array}$ & $\begin{array}{l}-0.397 \\
(2.191)\end{array}$ & $\begin{array}{c}5.446 \\
(15.311)\end{array}$ & $\begin{array}{c}12.083 \\
(16.815)\end{array}$ & $\begin{array}{c}-4.989 \\
(15.016)\end{array}$ \\
\hline $\operatorname{Igdp}$ & $\begin{array}{l}-0.01 \\
(0.01)\end{array}$ & $\begin{array}{l}-0.002 \\
(0.014)\end{array}$ & $\begin{array}{l}-0.009 \\
(0.015)\end{array}$ & $\begin{array}{l}-0.023 \\
(0.075)\end{array}$ & $\begin{array}{c}0.037 \\
(0.107)\end{array}$ & $\begin{array}{l}-0.031 \\
(0.098)\end{array}$ \\
\hline Credit & $\begin{array}{c}-1.836 \\
(0.861)^{* *}\end{array}$ & $\begin{array}{c}0.656 \\
(0.872)\end{array}$ & $\begin{array}{c}2.37 \\
(1.674)\end{array}$ & $\begin{array}{c}-10.98 \\
(6.252)^{*}\end{array}$ & $\begin{array}{c}7.503 \\
(8.235)\end{array}$ & $\begin{array}{c}13.7 \\
(12.414)\end{array}$ \\
\hline Educ & $\begin{array}{l}-0.038 \\
(0.107)\end{array}$ & $\begin{array}{c}0.024 \\
(0.113)\end{array}$ & $\begin{array}{l}0.088 \\
(0.17)\end{array}$ & $\begin{array}{c}-1.372 \\
(0.602)^{* *}\end{array}$ & $\begin{array}{l}-0.901 \\
(0.738)\end{array}$ & $\begin{array}{l}-0.751 \\
(0.995)\end{array}$ \\
\hline $\begin{array}{l}\text { Hansen p value } \\
\text { NOBs }\end{array}$ & $\begin{array}{c}0.17 \\
36\end{array}$ & $\begin{array}{c}0.49 \\
36\end{array}$ & $\begin{array}{c}0.37 \\
36\end{array}$ & $\begin{array}{c}0.11 \\
36\end{array}$ & $\begin{array}{c}0.28 \\
36\end{array}$ & $\begin{array}{c}0.14 \\
36\end{array}$ \\
\hline
\end{tabular}

Robust standard errors in parentheses; All regressions include constant term

* significant at $10 \%$; ** significant at $5 \%$; *** significant at $1 \%$

In all regressions we instrument for the governance indicators using distance from the equator (La Porta et al. (1998) and fraction of population speaking English and European languages (Hall and Jones (1998), Persson and Tabellini (2004)). 
Figure1: Bias in Public Education Spending and Good Governance

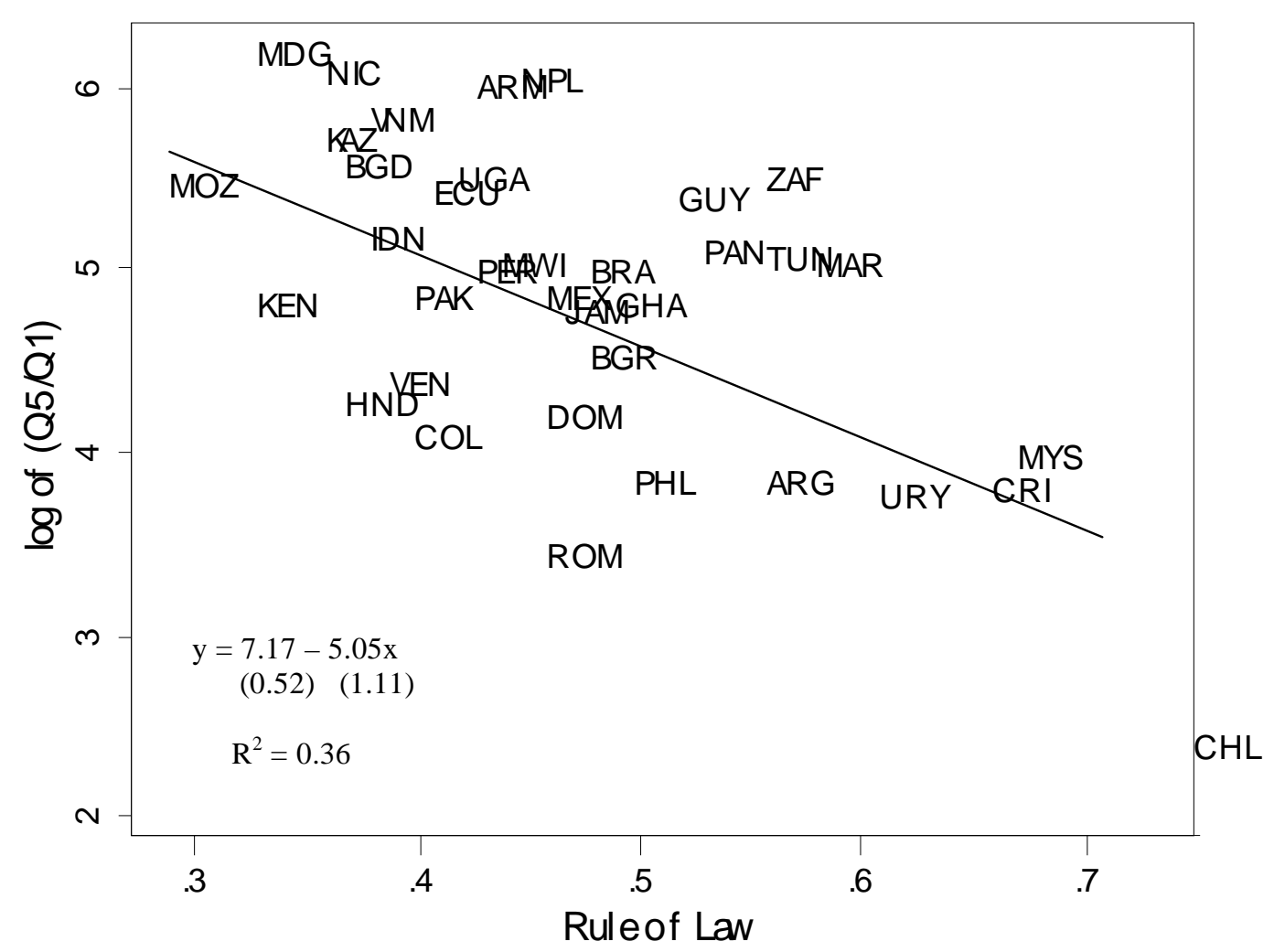

Note: The $\mathrm{Y}$-axis corresponds to the log of the benefit share of the wealthiest quiintile relative to the poorest in a cross-section of 36 developing countries in the 1990s. The $\mathrm{X}$-axis is an indicator of the rule of law. See Appendix for country codes and details on data sources. 
Figure 2: Convergence to a Steady State

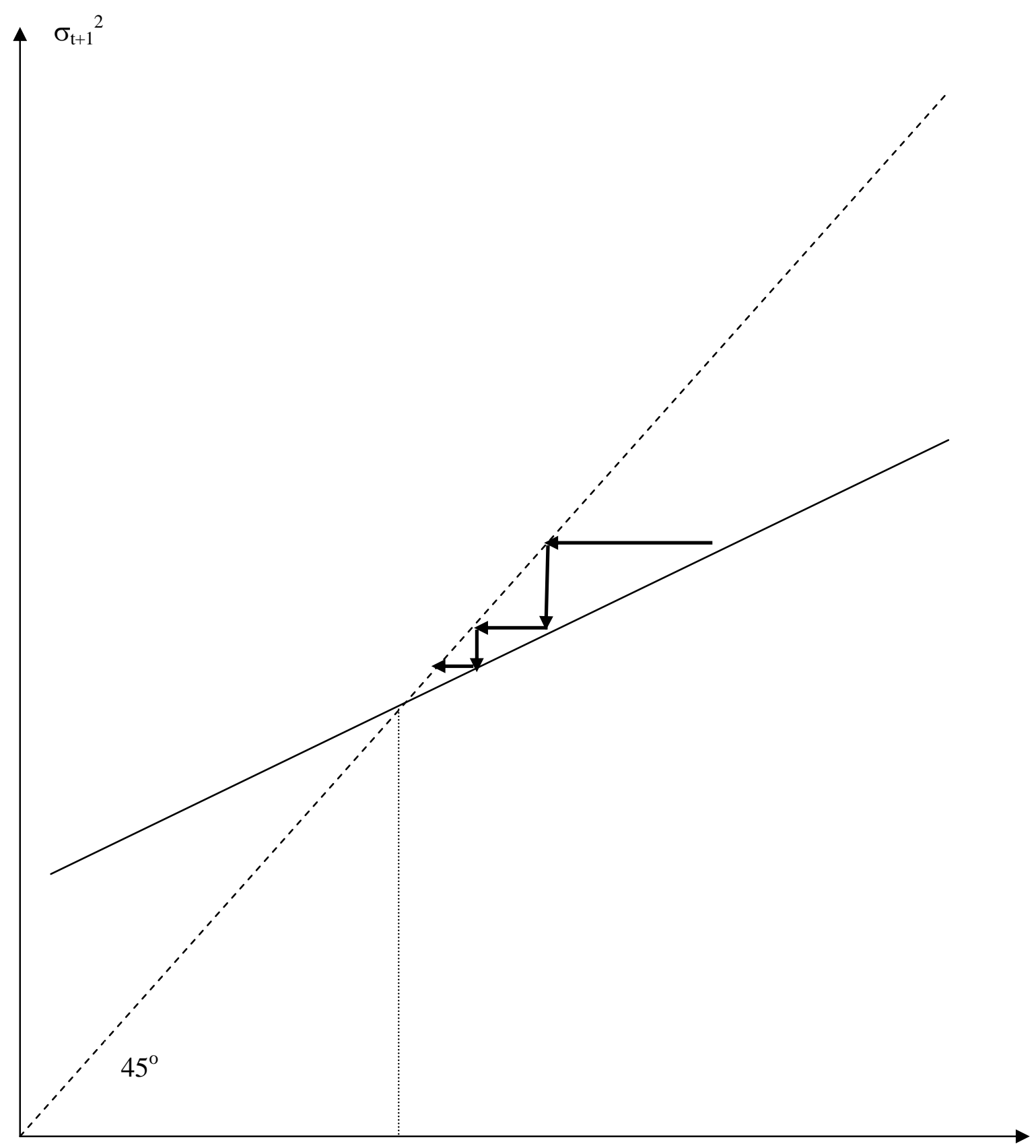




\section{Preferences Over Governance Quality}

Consider the individual preferences over governance quality. Differentiation of the utility function (8) with respect to $Q_{t}$ shows that it is convex. ${ }^{12}$ This implies that its optimum is obtained at one of the extreme values of $Q_{t}$. Letting $U_{i t}{ }^{0}$ denote the utility level under lowest quality and $U_{i t}{ }^{1}$ the utility level under highest quality, the welfare differential between the two regimes is calculated to be as follows:

$$
U_{i t}^{0}-U_{i t}{ }^{1}=\ln (1 /(1+\alpha))+\ln \left(y_{i t} / Y_{t}\right)^{\alpha}
$$

It increases with a household's income indicating that the richer the household the more favorable it is toward minimal governance quality. Also note that (A1) is negative when $y_{i t}=$ $Y_{t}$, indicating in particular that all households whose income is below the average favor maximal quality.

To the extent that the determination of institutional quality is done through voting, the outcome depends crucially on the distribution of voting power as it emanates from income distribution. Thus, suppose that political influence increases with income. The simplest way to capture this phenomenon is to assume that the identity of the decisive voter, $y_{d t}$, is given by:

$$
\ln \left(y_{d t}\right)=\mu_{\mathrm{t}}+\phi \sigma_{\mathrm{t}}^{2}
$$

where $\phi$ represents the extent of political bias in favor of the rich. If $\phi=0$, the median income voter is decisive; when $\phi=1 / 2$, the average income voter is decisive.

Then the utility differential for the decisive voter is:

$$
U_{d t}^{0}-U_{d t}^{1}=\ln (1 /(1+\alpha))+\ln \left(y_{d t} / Y_{t}\right)^{\alpha}=\ln (1 /(1+\alpha))+\alpha(\phi-1 / 2) \sigma_{t}^{2}
$$

implying that minimal governance quality wins the political support if the political bias or income inequality are large enough; under “one-man-one-vote” system high governance quality wins the majority support.

12 Our distributional assumptions imply that $\int_{0}^{1}\left(y_{j t}\right)^{1-Q_{t}} d j=\left(1-Q_{\mathrm{t}}\right) \mu_{\mathrm{t}}+\left(1-\mathrm{Q}_{\mathrm{t}}\right)^{2} \sigma_{\mathrm{t}}^{2} / 2$.

Differentiation of (8) then leads to: $d U_{i t} / d Q_{t}=-\alpha /\left(1+\alpha\left(1-\mathrm{Q}_{\mathrm{t}}\right)\right)+\alpha \ln \left(y_{i t}\right)-\alpha\left(\mu_{\mathrm{t}}+\left(1-\mathrm{Q}_{\mathrm{t}}\right) \sigma_{\mathrm{t}}^{2}\right) /$ $\left(\left(1-\mathrm{Q}_{\mathrm{t}}\right) \mu_{\mathrm{t}}+\left(1-\mathrm{Q}_{\mathrm{t}}\right)^{2} \sigma_{\mathrm{t}}^{2} / 2\right)$; and twice differentiating yields: $d^{2} U_{i t} / d Q_{t}^{2}=\alpha^{2} /\left(1+\alpha\left(1-\mathrm{Q}_{\mathrm{t}}\right)\right)^{2}-$ $\alpha\left[\sigma_{\mathrm{t}}^{2}\left(\left(1-\mathrm{Q}_{\mathrm{t}}\right) \mu_{\mathrm{t}}+\left(1-\mathrm{Q}_{\mathrm{t}}\right)^{2} \sigma_{\mathrm{t}}^{2} / 2\right)-\left(\mu_{\mathrm{t}}+\left(1-\mathrm{Q}_{\mathrm{t}}\right) \sigma_{\mathrm{t}}^{2}\right)^{2}\right] /\left(\left(1-\mathrm{Q}_{\mathrm{t}}\right) \mu_{\mathrm{t}}+\left(1-\mathrm{Q}_{\mathrm{t}}\right)^{2} \sigma_{\mathrm{t}}^{2} / 2\right)^{2}>0$. 
This, in turn, indicates the possibility of multiple trajectories, depending on the initial income inequality. If income inequality, $\sigma_{\mathrm{t}}^{2}$, is initially small then (A3) is negative and strong governance wins the political support. But then the variance of the income distribution is minimal as it is only due to the differences in abilities. In contrast, if initial income inequality is large enough so that (A3) is positive, weak governance wins the political support of the influential rich. This may then lead to the convergence to the equilibrium where weak governance is perpetuated - which happens whenever the political bias is large enough to lead to the subsequent increase in inequality.

\section{Summarizing,}

Proposition 3. When governance quality is determined through voting, only if the political bias in favor of the rich is large enough, low level of governance quality wins the political support. Moreover, in this case, depending on the degree of initial inequality, the economy may converge to multiple steady states, with weak governance and high inequality; or with strong governance and low inequality. 


\section{Data}

The ratio of public education spending accruing to the wealthiest quintile relative to the poorest (Q5/Q1) and the share accruing to the wealthiest quintile (Q5) were obtained from a cross country data compiled by Davoodi et al. (2003) on the incidence of education spending for over 50 countries. The data set is based on existing studies that utilize benefit incidence analysis (BIA) (see Table A1). Due to interactions with our independent variables, our sample is restricted to 36 developing countries for whom BIA analysis was conducted in the 1990s.

\section{Dependent variables}

Rule of Law: point estimate of "Rule of Law" from Kaufmann et. al governance indicators, averaged over the 1990s. It is rescaled to 0-1, with higher scores corresponding to better outcomes. Source: Kaufmann et al. (1999).

Regulatory quality: point estimate from Kaufmann et. al governance indicators, averaged over the 1990s. It is rescaled to 0-1, with higher scores corresponding to better outcomes. Source: Kaufmann et al. (1999).

Gastil: average of indices for civil liberties and political rights, averaged over the 1980-89 period. The index varies on a discrete scale from 1 to 7 , with low values associated with better democratic outcomes. We rescaled these variables to $0-1$, with higher scores implying better governance quality or a greater constraint on the capacity of the rich to influence policy. Source: Freedom House, Annual Survey of Freedom Country Ratings.

Gini: measurement-adjusted gross income Gini in 1990 or closest available. Source: Deinenger and Squire (1996) and Milanovic (2002).

Educ: proxy for the initial level of schooling and education in the country. Average years for population aged 25 or above in 1990. Source: Barro and Lee (2001).

Credit: claims of financial institutions on the private sector as a share of GDP. Source: Beck et. al (2000) from IFS data (IMF)

IGDP: real gdp per capita in PPP terms averaged over the 1980-89 period,. Source: Penn World Tables Mark 6.1 database. 
Table A1: Benefit Incidence of Public Spending on Education

\begin{tabular}{|c|c|c|c|c|}
\hline Country & Code & $\begin{array}{c}\text { Poorest Quintile } \\
\text { Q1 }\end{array}$ & $\begin{array}{c}\text { Wealthiest Quintile } \\
\text { Q5 }\end{array}$ & $\begin{array}{c}\text { Bias } \\
\text { Q5/Q1 }\end{array}$ \\
\hline Argentina & ARG & 29 & 13.5 & 0.5 \\
\hline Armenia & ARM & 7 & 29.0 & 4.1 \\
\hline Bangladesh & BGD & 12 & 32.0 & 2.7 \\
\hline Bulgaria & BGR & 20 & 19.1 & 1.0 \\
\hline Brazil & BRA & 16 & 24.0 & 1.5 \\
\hline Chile & CHL & 42 & 4.6 & 0.1 \\
\hline Colombia & COL & 23 & 14.2 & 0.6 \\
\hline Costa Rica & CRI & 27 & 12.1 & 0.5 \\
\hline Dominican Republic & DOM & 23 & 15.7 & 0.7 \\
\hline Ecuador & ECU & 11 & 26.0 & 2.4 \\
\hline Ghana & GHA & 16 & 20.8 & 1.3 \\
\hline Guyana & GUY & 15 & 32.1 & 2.2 \\
\hline Honduras & HND & 20 & 14.9 & 0.7 \\
\hline Indonesia & IDN & 16 & 29.0 & 1.8 \\
\hline Jamaica & JAM & 18 & 21.8 & 1.2 \\
\hline Kazakhstan & KAZ & 8 & 26.0 & 3.1 \\
\hline Kenya & KEN & 17 & 20.7 & 1.2 \\
\hline Morocco & MAR & 15 & 22.8 & 1.5 \\
\hline Madagascar & MDG & 8 & 41.2 & 5.0 \\
\hline Mexico & MEX & 17 & 22.0 & 1.3 \\
\hline Mozambique & MOZ & 14 & 32.9 & 2.4 \\
\hline Malawi & MWI & 16 & 25.0 & 1.6 \\
\hline Malaysia & MYS & 26 & 14.0 & 0.5 \\
\hline Nicaragua & NIC & 9 & 40.1 & 4.4 \\
\hline Nepal & NPL & 11 & 46.0 & 4.4 \\
\hline Pakistan & PAK & 16 & 21.7 & 1.3 \\
\hline Panama & PAN & 12 & 21.2 & 1.7 \\
\hline Peru & PER & 15 & 22.1 & 1.5 \\
\hline Philippines & PHL & 29 & 13.7 & 0.5 \\
\hline Romania & ROM & 31 & 10.0 & 0.3 \\
\hline South Africa & ZAF & 14 & 34.9 & 2.5 \\
\hline Tunisia & TUN & 16 & 25.4 & 1.6 \\
\hline Uganda & UGA & 13 & 32.0 & 2.5 \\
\hline Uruguay & URY & 33 & 14.6 & 0.4 \\
\hline Venezuela & VEN & 22 & 18.1 & 0.8 \\
\hline Vietnam & VNM & 11 & 37.9 & 3.4 \\
\hline
\end{tabular}

Source: Davoodi et al. (2003) 


\section{REFERENCES}

Banerjee, A., and A. Newman, 1993, "Occupational Choice and the Process of Development,” Journal of Political Economy, Vol. 101 (April) pp. 274-98.

Barro, R., 1991, “Economic Growth in a Cross Section of Countries,” Quarterly Journal of Economics, Vol. 106 (May), pp. 407-43.

— Implications,” Oxford Economic Papers, Vol. 53, No. 3, pp. 541-63.

Beck, T., A. Demirgüç-Kunt, and R. Levine, 2000, “A New Database on Financial Development and Structure,” World Bank Economic Review, Vol. 14 (September), pp. 597-605.

Bertocchi, D., and M. Spagat, 2004, “The Evolution of Modern Educational Systems: Technical vs. General Education, Distributional Conflict, and Growth,” Journal of Development Economics, Vol. 73, No. 2, pp. 559-82.

Birdsall, N., 1997, "Public Spending on Higher Education in Developing Countries: Too Much or Too Little?” Economics of Education Review, Vol. 15, No. 4, pp. 407-19.

Bourguignon, F., and T. Verdier, 2000, “Oligarchy, Democracy, Inequality and Growth,” Journal of Development Economics, Vol. 62 (August), pp. 285-313.

Castello, A., and R. Domenech, 2002, "Human Capital Inequality and Economic Growth: Some New Evidence,” Economic Journal, Vol. 112 (March), pp. C187-200.

Chong, A., and M. Gradstein, 2004, “Inequality and Institutions” (unpublished; Washington: Inter-American Development Bank).

Davoodi, H.R., E.R.Tiongson, and S.S. Asawanuchit, 2003, “How Useful Are Benefit Incidence Analyses of Public Education and Health Spending,” IMF Working Paper 03/227 (Washington: International Monetary Fund).

Deininger, K., and L. Squire, 1996, “A New Data Set Measuring Income Inequality,” World Bank Economic Review, Vol. 10 (September), pp. 565-91.

Doepke, M., and D. de la Croix, 2004a, "Public Versus Private Education when Differential Fertility Matters,” Journal of Development Economics, Vol. 73 (February), pp. 607-29.

_ 2004b, “To Segregate or to Integrate: Education Politics and Democracy,” CEPR Discussion Paper No.390 (London: Centre for Economic Policy Research). 
Epple, D., and R. Romano, 1996, "Public Provision of Private Goods," Journal of Political Economy, Vol. 104 (February), pp. 57-84.

Esping-Anderson, G., 1990, The Three Worlds of Welfare Capitalism (Cambridge, UK: Polity Press).

Ferreira, F., 2001, "Education for the Masses?: The Interaction Between Wealth, Educational and Political Inequalities," Economics of Transition, Vol. 9, No. 2, pp. 533-52.

Galor, O., and J. Zeira, 1993, "Income Distribution and Macroeconomics," Review of Economic Studies, Vol. 60, No. 1, pp. 35-52.

Gelbach, J.B, and L. Pritchett, 2002, "Is More for the Poor Less for the Poor? The Politics of Means-Tested Targeting," The B.E. Journals in Economic Analysis and Policy, Vol. 2, No. 1, pp. 1-26.

Gradstein, M., 2004, “Voting on Meritocracy,” European Economic Review, Vol. 48, No. 4, pp. 797-803.

—_ and M. Justman, 1997, "Democratic Choice of an Education System: Implications for Growth and Income Distribution,” Journal of Economic Growth, Vol. 2, pp. 169-83.

Gylfason, T., and G. Zoega, 2003, "Education, Social Equality and Economic Growth: A View of the Landscape," CESifo Economic Studies, Vol. 49, No. 4, pp. 557-79.

Hall, R., and C. Jones, 1999, "Why Do Some Countries Produce So Much Output Per Worker than Others," Quarterly Journal of Economics, Vol. 114 (February), pp. 83-116.

Hwang, J., 2004, “Asset Distribution and Tertiary Education Expenditures in Developing Countries," Economics of Education Review (forthcoming).

Knack, S., and P. Keefer, 1995, "Institutions and Economic Performance: Cross-country Tests Using Alternative Institutional Measures,” Economics and Politics, Vol. 7 (November), pp. 207-27.

La Porta, R., F. Lopes-de-Silanes, A. Shliefer, and R. Vishny, 1998, "Law and Finance,” Journal of Political Economy, Vol. 106 (December), pp. 1113-55.

Le Grand, J., 1982, The Strategy of Equality: Redistribution and the Social Services (London: George Allen and Unwin).

Mankiw, G.N., D. Romer, and D.N. Weil, 1992. "A Contribution to the Empirics of Economic Growth,” Quarterly Journal of Economics, Vol. 107 (May), pp. 407-37. 
Meltzer, A.H., and S.F. Richard, 1981, “A Rational Theory of the Size of Government,” Journal of Political Economy, Vol. 79 (October), pp. 914-27.

Milanovic, B., 2002, Worlds Apart: International and World Inequality 1950-2000 (Washington: World Bank).

Nitzan, S., 1994, “Modeling Rent-Seeking Contests,” European Journal of Political Economy, Vol. 10 (November), pp. 41-60.

Ravallion, M., 1999, “Are Poorer States Worse at Targeting their Poor?” Economics Letters, Vol. 65, No. 3, pp. 373-76.

Rodrik, D., A. Subramanian, and F. Trebbi, 2002, “Institutions Rule: The Primacy of Institutions Over Geography and Integration in Economic Development” (unpublished; Washington: International Monetary Fund).

Su, X., 2004, “The Allocation of Public Funds in a Hierarchical Education System,” Journal of Economic Dynamics and Control, Vol. 28 (December), pp. 2485-2510.

World Bank, 2001, World Bank Development Report: Attacking Poverty (New York: Oxford University Press; Washington: World Bank).

World Bank, 2004, World Bank Development Report: Making Services Work for Poor People (New York: Oxford University Press; Washington: World Bank). 